Petra PotMesilova, MiLON PotMesil

Palacky University Olomouc

Czech Republic

MAGDALENA BEŁZA

Uniwersytet Ślaski w Katowicach

WEiNoE w Cieszynie, Poland

\title{
HEARING IMPAIRMENT AND ITS REFLECTION IN PSYCHOLOGICAL DIAGNOSTICS ${ }^{1}$
}

\begin{abstract}
Potmesilova Petra, Potmesil Milon, Bełza Magdalena, Hearing Impairment and its Reflection in Psychological Diagnostics [Upośledzenie stuchu i jego odzwierciedlenie w diagnostyce psychologicznej]. Studia Edukacyjne nr 42, 2016, Poznań 2016, pp. 415-433. Adam Mickiewicz University Press. ISSN 1233-6688. DOI: $10.14746 /$ se.2016.42.24

The authors hereby present a report on research aimed at the possibilities of adjustments of psychodiagnostic materials to be used in the population of children with hearing impairments in order to reduce or eliminate the functional impact of the defect on the child's performance and consequently on the diagnostic process. The adjustment was made by formal language modification without intervention in the content, and by the creation of a version in Czech sign language. The B-J.E.P.I. personality questionnaire and a comprehension subtest using the Wechsler intelligence scale for children (further WISC-III) were experimentally modified and tested in practice between 2011 and 2016.
\end{abstract}

Key words: hearing impairment, psychological diagnostics, psychosocial context of hearing impairment

\section{Hearing Impairment and its Reflection in Psychological Diagnostics. Introduction to the Issue}

The term hearing loss covers a very wide range of problems that have to be dealt with in connection with the concept and objectives of psychological

1 This article was supported by grants: IGA_CMTF_2015_010 and IGA_PdF_2015_013. 
diagnostics and subsequent intervention. ${ }^{2}$ An individual deficit takes on a handicap dimension within the psychosocial context, defined as a reflection of given personal insufficiency, intensified by the reduced success of functioning in society at large that does not suffer from a hearing loss. ${ }^{3}$ Regardless of different views on the objectives of educating children with a hearing loss, everything is focused on increased efforts aiming at a reduced impact of the deafness on the psychosocial development of the children, using compensatory procedures, and at achieving the highest possible level of development. ${ }^{4}$

The solution is a timely start of rehabilitation, the optimum being comprehensive rehabilitation. This strategy is based on timely diagnosis and timely indication of compensation aid and psychological intervention, so that an individual intervention plan can immediately follow, to be applied from an early age, with the objective being to meet all the requirements of a successful upbringing and education before elementary school.

One of the serious impacts of a hearing loss is reduced language acquisition, and starting with school age a major deficit in the ability to read and understand. Therefore dealing with the above-mentioned insufficiency is considered to be one of the most important goals of the endeavor to compensate for a hearing loss. Reading with comprehension is accepted as the basis for a successful educational process, and in the wider context a basis for successful socialization. Technical reading with children suffering from deafness is usually handled rather well. ${ }^{5}$ However, here the Czech language presents itself in all its complexity, especially the high level of inflection, which in the global way of reading basically prohibits remembrance of all the grammatically correct versions of actively used words, resulting in a situation where reading as a source of learning or reading as entertainment present a serious problem for most children and adults with a hearing loss. ${ }^{6}$

The reader does not understand the text and its content, losing motivation for such an activity that brings neither satisfaction nor fun. Maybe this

${ }^{2}$ Guidelines for assessment of and intervention with persons with disabilities, 2012

${ }^{3}$ P. Gates-Ulanet, N.K. Mellon, Psychosocial Aspects of Hearing Loss in Children, Otolaryngologic Clinics of North America, 2015, 48 (Hearing Loss in Children), p. 1073-1080.

4 P.G. Jacobs, Psychosocial Potential Maximization: A Framezork of Proactive Psychosocial Attributes and Tactics Used by Individuals who are Deaf, Volta Review, 2010, 110(1), p. 5-29.

5 A.R. Lederberg, B. Schick, P.E. Spencer, Language and literacy development of deaf and hardof-hearing children: Successes and challenges, Developmental Psychology, 2013, 49(1), p. 15-30.

6 M.T. Daza et al., Language skills and nonverbal cognitive processes associated with reading comprehension in deaf children, Research in Developmental Disabilities, 2014, p. 3526-3533; C. Williams, C. Mayer, Writing in Young Deaf Children, Review of Educational Research, 2015, 85(4), p. 630. 
is why the exceptional cases of people able to read with comprehension are so important. For these reasons reading lessons are a major topic both in the Czech Republic and abroad (see: Souralová, 2002; Velehradská \& Kuchler, 1998; Macurová, 2000; Poláková, 2001). With regard to research activities this field has a long tradition beyond our borders; recently, for example (see: Coppens, 2013; Huremovic \& Sulejmanovic, 2011; Hutchison, 2007).

In connection with the problem described above it is necessary to mention Pylyshyn's term 'cognitive penetrability'. ${ }^{7}$ This is a form of dependence of the psychological process on conceptual and rational-logical dealing with the content. The possibility of cognitive penetrability is thus due to conscious intention, conceptual rational-logical operations and expressions with the same content as the vision. While content compliance is based on the fact that the essence of a vision is equal to the essence of a corresponding expression, at the same time it allows reflection and corrections of the relationship. Therefore the level and quality of cognitive penetrability determines to what level it will be possible to express the reflected visions in words. ${ }^{8}$ Cognitive penetrability isaprecondition for the inter-subjective mediation of ideas in words, or non-verbal expressions (understanding), because it is a precondition of the intentional expression of ideas. ${ }^{9}$ Therefore it is important to what extent and quality an idea is expressed in relevant words or non-verbal signals; this quality is then put to the test in communication with others. ${ }^{10}$ The respondent expresses his/her understanding of the idea, verifying the possibility of understanding others.

Language competences and the level of their utilization are not just a basis for efficient educational schoolwork with children and pupils suffering from a hearing loss; it is directly reflected in the entire psychological diagnostics and subsequent intervention. It should be pointed out here that this does not mean only those children sent to schools with special educational programs - the need for psychological diagnostics and interventions also relates to children in the inclusive education system. One of the major problems of inclusive education is the fact that children or pupils (with a hearing loss, but from the cultural-anthropological viewpoint with any handicap) suffer from a lack of communication or behavioral patterns, and conse-

7 E.g. A. Chasid, Visual Experience: Cognitive Penetrability and Indeterminacy, Acta Analytica: International Periodical for Philosophy in the Analytical Tradition, 2014, 29(1), p. 119-130; E.R. Fridland, Skill, Non Propositional Thought, and the Cognitive Penetrability of Perception, Journal For General Philosophy of Science, 2015, 46(1), p. 105-120.

8 J. Slavík, V. Chrz , S. Štech, Tvorba Jako Způsob Poznávání, Praha 2013, p. 89.

9 O. Deroy, Object-Sensitivity versus Cognitive Penetrability of Perception, Philosophical Studies: An International Journal For Philosophy in The Analytic Tradition, 2013, 162(1), p. 87-107.

${ }^{10}$ A. Raftopoulos, Cognitive Penetrability and Consciousness, Oxford 2015. 
quently from a lack of the relevant stimuli necessary for the development of their personality. The issue of the transfer of a negative effect of hearing loss to the building up of a personality structure in adulthood is elaborated by. ${ }^{11}$ Children with deafness of parents with a hearing loss are in an "ideal" situation regarding language acquisition and the related competences. ${ }^{12}$ The development of communication skills in a family environment where people use sign language to communicate is fully comparable to the conditions in a family where there is no hearing handicap. In addition, especially in this case the levels of cognitive functions and communicative and social competences can be expected to be at a level comparable with those of children not suffering from a hearing loss. ${ }^{13}$ Intellect will be a major variable here, which can be described very accurately from the point of view of psychological diagnostics. For instance, for children who have normally developed communicative competences and language before starting school, intellect and the related social competences should be evaluated as significant values that determine their inclusion in a certain educational program. ${ }^{14}$ It can be derived from the above that when children are being evaluated during school enrollment they can undergo the same procedure as hearing children, with one difference: sign language is used.

\section{Research Description}

Considering the above, the requirements on a psychologist and an examination or intervention focusing on children with a hearing loss are very specific. It is necessary to diagnostically separate the hearing loss and its consequences (effects on the development of language and communication skills, a certain backwardness in the field of social skills and the concept of social relations), and using suitable instruments, for example, measure the intellectual level and possibly describe the lower intellect so that it is clear whether the issue is primarily a lower IQ or just a general delay resulting

${ }_{11}$ M. Harris, The Rise of Anthropological Theory: A History of Theories of Culture, London 2001; M. McKee, D. Schlehofer, D. Thew, Ethical Issues in Conducting Research With Deaf Populations, American Journal of Public Health, 2013, 103(12), p. 2174-2178.

12 K. Hofmann, S. Chilla, Bimodal Bilingual Language Development of Hearing Children of Deaf Parents, European Journal of Special Needs Education, 2015, 30(1), p. 30-46.

13 A.A. Zekveld et al., The Relationship Between Nonverbal Cognitive Functions and Hearing Loss, Journal of Speech, Language \& Hearing Research, 2007, 50(1), p. 74-82.

14 M. Harrington, J.L. DesJardin, L.C. Shea, Relationships Between Early Child Factors and School Readiness Skills in Young Children With Hearing Loss, Communication Disorders Quarterly, 2010, 32(1), p. 50. 
from a reduced ability to hear and receive stimuli and respond to them. There are similar demands related to other examinations and diagnostic activities performed with children and young people. ${ }^{15}$ In this context they will most probably include diagnostic, intervention-preventive and therapeutic work. All these items within the wide range of activities incorporate the requirement for handling the language and efficient communication and understanding. These are basic prerequisites for reaching a certain level of efficiency and validity of psychological diagnostic.

\subsection{Adjustment of the B-J.E.P.I. Questionnaire}

The B-J.E.P.I. Questionnaire used in the Czech Republic was created by the translation and adoption of the English version, J.E.P.Q. (E.P.Q./Junior), by J. Senka. Czech and Slovak standards were elaborated for the questionnaire.

The currently used version (in Czech Republic) was published in 1994 and belongs among the most commonly used tools (Svoboda, 2001, p. 343) in our country, focusing on the 9-14 age group. For experimental purposes Senka recommends also using the questionnaire with older children up to 15. There are different specific tools that have been developed for the 15+ category.

The questionnaire focuses on four scales: $\mathrm{E}$ (extraversion-introversion), $\mathrm{N}$ (lability-stability), P (psychoticism) and L (lie score).

Extraversion-introversion is a scale based on behavior, related to the person's relationship with the environment and the dynamics of his/her behavior. The $\mathrm{N}$ scale expresses the movement from lability to stability. According to Eysenck, a high score for psychoticism is a manifestation of personality that experiences problems with adaptability and indicates a withdrawn loner. The relationship to other people ranges from insensitivity to inhuman cruelty. A high $\mathrm{P}$ score points out a possible disorder of an autistic nature. The list ends with the L scale (lie score). It expresses the measure of social desirability. Svoboda describes it as a stable personality feature that could be related to acceptance of a role within social activity. We can assume that the $\mathrm{L}$ score value can be considered a manifestation of social competence. According to Senka, the lie score describes the tendency to dissimulation and its level.

${ }^{15}$ M. Koopmann, D. Weiss, C. Rudack, A rare differential diagnosis of deafness, LaryngoRhino- Otologie, 2013, 92(2), p. 115-116. 


\subsection{Administration of the B-J.E.P.I. Questionnaire}

Both Senka (1994) and Svoboda (2001) describe individual or group administration, usually not longer than 20 minutes. The proband replies with yes or no, and the reply has to be fast and unambiguous. The reply is marked with a circle. Examination in the 8-14 age group should be smooth, as the children are already developed enough to perform independent work and able to proceed when supervised by an unknown person Vágnerová and Klégrová. ${ }^{16}$ Understanding of authority differences can be studied in Orwin's paper (1971).

However some authors ${ }^{17}$ claim that filling in the questionnaire by individuals with a hearing loss is often accompanied by a lack of concentration and a low capacity for independent work. But this has not been proved.

\subsection{Respondents}

The sample of respondents consisted of pupils of so-called "basic schools" (the basic school is a form of school in the Czech Republic where children aged 6-15 receive their compulsory education) for children with deafness who were 9-15 years of age. To be included in the sample the child had to suffer from a hearing loss. The respondents were from all around the country; the survey was allowed in almost all schools. Questionnaires were completed by a sample of 137 children with a deafness, and two questionnaires were excluded because of missing data on age or gender. When planning the experimental part we were informed by the principals of the collaborating schools that in the year 2013/14 the subject age group in the elementary schools for children with a hearing loss included about $160 \mathrm{pu}-$ pils. The collected data therefore describe some $85 \%$ of this population in this country (who attended special schools). In the first round 135 children with a deafness, aged 9-15, participated in the research. There were 73 boys and 62 girls. The second round, the retest, was carried out on a sample of 40 children ( 23 boys and 17 girls). 104 hearing fathers and 103 hearing mothers 2008.

${ }^{16}$ M. Vágnerová, J. Klégrová, Poradenská psychologická diagnostika dětí a dospívajících, Praga

17 B. Lyxell et al., Chapter 4: Hearing and cognitive development in deaf and hearing-impaired children. effects of intervention, Handbook of Clinical Neurophysiology, (Disorders of Peripheral and Central Auditory Processing), 2013, 10, p. 71-80; M. Harrington, J.L. DesJardin, L.C. Shea, Relationships Between Early Child Factors and School Readiness Skills, p. 50; F. Ebrahim, Comparing Creative Thinking Abilities and Reasoning Ability of Deaf and Hearing Children, Roeper Review, 2006, 28(3), p. 140-147. 
were represented in the first round. There were 32 hearing fathers and mothers in the second round. There were 29 fathers and 29 mothers with a deafness in the first round, and seven in the second round. Other respondents did not fill in this field. This means there were about $77 \%$ and $80 \%$ of respondents with hearing parents in the two rounds.

Frequency of gender in the rounds

Table 1

\begin{tabular}{|l|c|c|c|c|}
\hline Gender & Number 1st round & Percentage & $\begin{array}{c}\text { Number 2nd } \\
\text { round }\end{array}$ & Percentage \\
\hline Boys & 73 & 54 & 23 & 57 \\
\hline Girls & 62 & 46 & 17 & 43 \\
\hline Sum & $\mathbf{1 3 5}$ & $\mathbf{1 0 0}$ & $\mathbf{4 0}$ & $\mathbf{1 0 0}$ \\
\hline
\end{tabular}

Table 2

Age structure of respondents in the rounds

\begin{tabular}{|c|c|c|c|c|}
\hline Age & $\begin{array}{c}\text { Number } 1^{\text {st }} \\
\text { round }\end{array}$ & Percentage & $\begin{array}{c}\text { Number 2nd } \\
\text { round }\end{array}$ & Percentage \\
\hline 9 & 5 & 4 & 2 & 5 \\
\hline 10 & 6 & 4 & 4 & 10 \\
\hline 11 & 17 & 13 & 4 & 10 \\
\hline 12 & 21 & 15 & 9 & 22 \\
\hline 13 & 28 & 21 & 5 & 12 \\
\hline 14 & 40 & 30 & 7 & 18 \\
\hline 15 & 18 & 13 & 9 & 23 \\
\hline Sum & $\mathbf{1 3 5}$ & $\mathbf{1 0 0}$ & $\mathbf{4 0}$ & $\mathbf{1 0 0}$ \\
\hline
\end{tabular}

\subsection{Description of Formal Adjustments of B-J.E.P.I.-SP Questionnaire}

The data were collected using an adjusted questionnaire titled B-J.E.P.I.$\mathrm{SP}(\mathrm{SP}=$ variant for respondents with deafness).

In the first step the questionnaire was presented to the pupils of one of the cooperating schools for children with deafness, with the request to fill in the forms and comment on their comprehensibility. Difficult or incomprehensible sections were identified using the guided interview method. The text was subsequently modified, while corresponding to the original wording. In some cases it was sufficient to highlight a key word or expression. 
The next step was consultation with a colleague suffering from a hearing loss who is a native user of sign language, a university lecturer with years of previous experience as a teacher at an elementary school for children with deafness. The final adjustments based on his recommendations led to a pilot version of the text and an accompanying version in sign language. The sign language version was developed to include the entire administration with an introduction and explanation of the process. Every item of the questionnaire in the video version is separated by a text with the respective question, and it is possible to stop the video as needed; the children can go back to individual statements. This version was submitted to the pilot group again after three months. Regardless of the results, as regards the respondents' personalities, their comments were obtained in a follow-up interview, confirming the comprehensibility of both the text and the video of the administration of the survey in sign language. Thus a final version of the adjusted questionnaire for the research was created.

The formal modification of the original questionnaire items was based on the assumption that reading with comprehension is difficult for children with deafness, and the formulations have to be adjusted to ensure understanding and relevant replies, i.e., to reduce the functional impact of deafness on the results. In some cases the formulation was modified, and in some statements only selected words were highlighted. The objective was to ensure test reliability.

Example of Formal Adjustment of Questionnaire Items:

Table 3

Formal adjustment of questionnaire

\begin{tabular}{|l|l|}
\hline \multicolumn{1}{|c|}{ ORIGINAL ITEM } & \multicolumn{1}{c|}{ ADJUSTED ITEM } \\
\hline $\begin{array}{l}\text { Do you usually reply promptly when } \\
\text { somebody talks to you? }\end{array}$ & $\begin{array}{l}\text { Do you usually reply immediately when } \\
\text { somebody talks to you? }\end{array}$ \\
$\begin{array}{l}\text { Do you often feel very uncomfortable } \\
\text { without a clear reason? }\end{array}$ & $\begin{array}{l}\text { There is no reason and yet very often you } \\
\text { feel uncomfortable. }\end{array}$ \\
\hline
\end{tabular}

\section{Results of Adjustments}

The reliability of the test was first established using the Cronbach's alpha for individual scales. 
Reliability for individual scales

\begin{tabular}{|c|c|}
\hline Scale & Cronbach's alpha \\
\hline $\mathrm{P}$ &, 682 \\
\hline $\mathrm{E}$ &, 732 \\
\hline $\mathrm{N}$ &, 727 \\
\hline $\mathrm{L}$ &, 605 \\
\hline
\end{tabular}

Apart from the L scale, the value of the Cronbach's alpha can be considered sufficient. To verify the compliance of repeated measurement in time a test-retest method was used. The results of both measurements were then statistically processed using a T-test and U-test for individual independent groups. No statistically significant difference was identified on the basis of the above-mentioned test between medians and the distribution of values within individual scales at the level of significance of 0.05 , which led to the conclusion that no different results had been recorded.

The next step in the description of the responses of the children with deafness to the formally modified questionnaire was to compare the results of these children with the results of the corresponding intact population. A T-test for medians was used for the comparison. A statistically significant difference was identified in the medians on the P and L scales, with a level of 0.05 .

The results hint at a higher level of psychoticism in the group of children with a deafness. Let us go back to the aforementioned authors - Vágnerová (2010) and Svoboda (2001) - and their characteristics of psychoticism. Both agree in principle that a high level of psychoticism is a source of low social adaptability. Řičan (2010) speaks about a specific type of creativity with regard to social behavior. Savastano ${ }^{18}$ and his team and similarly Savoldelli $(2007)^{19}$ confirmed a significantly higher level of psychoticism in their cohorts of probands with a hearing loss. Psychoticism is defined as a certain disruption of the social adaptability of an individual, manifested in lower conformity, inability to adapt and perhaps emotional blunting; it is clear, then, that children with deafness will have higher scores on the P scale, because their social skills and functioning are negatively affected by deafness

18 M. Savastano, Characteristics of tinnitus in childhood, European Journal of Pediatrics, 2007, 166(8), p. 797-801.

${ }^{19}$ G. Savoldelli, Extraversion (E), Neurotizismus (N) und Psychotizismus (P) bei Gehörlosen und Ertaubten, Archiv Für Psychiatrie Und Nervenkrankheiten, 1975, 220(3), p. 213. 
and consequent markedly lower social competences, as compared to their hearing contemporaries.

Other results point out the slight tendency of children with deafness to desirability. It can be interpreted as a personality trait of an individual striving to manifest desirable or expected behavior. But this is not always necessarily a tendency to lying. The lower scores of children with a hearing loss can be explained by the fact that at this age they have already clearly established rules of "school" behavior and self-presentation in the school or a similar environment. On the other hand, the higher values of the group with deafness can be explained as a result of their lower level of social experience and worse access to non-intentional and social learning as the most important sources, as a result of their limited language and communication skills. For example, Traxler ${ }^{20}$ describes a higher $(80 \%)$ L score during another opportunity to test probands with deafness.

\section{Partial Conclusions}

The modification and verification of the B-J.E.P.I. personality questionnaire was completed to make it usable in the diagnostics of children with deafness and to eliminate inaccuracies caused by the specific features of their cognitive and social development. By examining a relatively large sample (85\% of the population with deafness) we collected data on the personality features of these children and compared them with the results and standards of intact children. Thanks to the formal language modifications and the creation of a version in Czech sign language, including the administration instructions, it was possible after verification to propose the BJ.E.P.I. - SP questionnaire as a diagnostic tool whose validity and reliability have been confirmed for the group of children with deafness. The standard was revised for this group, using the results that were collected.

\section{WISC-III}

Wechsler defined intelligence as a complex global function that consists of partial, mutually independent abilities: the ability to act in a purposeful

${ }^{20}$ C.B. Traxler, The Stanford Achievement Test, 9th Edition: National Norming and Performance Standards for Deaf and Hard-of-Hearing Students, Journal of Deaf Studies and Deaf Education, 2000, 5(4), p. 337-348. 
manner, to think rationally and interact efficiently with the environment. ${ }^{21}$ Following this approach to intelligence he created the first version of an intelligence test in 1939; it has been modified and revised a number of times. The Czech version, developed by Krejčŕřová, Boschek and Dan, was published in 2002. The test is designed for children and young people aged 6-17 years old, and serves the purpose of evaluating their overall level of intellectual abilities. It consists of a total of 13 sub-tests, which can be divided into two scales: verbal and performance.

On the basis of a theoretical outline and results from practice,22 (Vágnerová, 1993; Krejčířová, 2001; Šedivá, 2006; Vernon, 2005; Slate \& Fawcett, 1995; Marschark, 1997) it is possible to conclude that there can be disproportionate results on the verbal and performance scales in the tests done by children with deafness. For this reason, an adaptation of the Comprehension subscale was created as a pilot (verbal scale) for these children. The objective was to collect information about a tool that would measure the verbal intelligence of individuals with deafness, and not reading with comprehension. ${ }^{23}$

\subsection{Respondents}

42 and 35 respondents with deafness, aged 11-15 years old, participated in the firat and second rounds of the research, respectively.

\subsection{Method}

The first administration of the Comprehension subtest (42 respondents) was carried out according to the rules of test administration. The items were used unchanged. However, the administration was not completed after three consecutive failures (see the rules), and yet all the children were presented with all the questions. The objective was to collect all the necessary information for the next step: formal adjustment of the items and conversion to sign language. The second administration (35 respondents) was performed with the same sample six months later in a modified version. The

${ }^{21}$ D. Wechsler, The measurement of adult intelligence (3rd ed.), Baltimore 1944, p. 3.

22 K. Zborteková, Integrované vzdelávanie a kognitívny Vývin sluchovo postihnutých detí, Psychológia a patopsychológia diet'at'a", 2000, 1(35), p. 57-66.

${ }^{23}$ A.R. Lederberg, B. Schick, P.E. Spencer, Language and literacy development of deaf, p. 15-30. 
modification comprised formal adjustment of the text and its conversion to sign language.

Formal adjustment was based on the fact that it is difficult for children deafness to read written texts (see above), and the original wording focuses more on reading with comprehension, not understanding of the given situation:

Table 5

Formal adjustment of test

\begin{tabular}{|l|l|}
\hline \multicolumn{1}{|c|}{ Original item } & \multicolumn{1}{c|}{ Adjusted item } \\
\hline $\begin{array}{l}\text { What are you to do when you cut your } \\
\text { finger? }\end{array}$ & $\begin{array}{l}\text { You are cutting something and you cut } \\
\text { your finger. What will you do? }\end{array}$ \\
\hline
\end{tabular}

All the other items were adjusted similarly. (The wording of the adjusted items is available in both Czech and English). The basic rule was that the situation has to be described first, and only then can the question be asked. Thus the task becomes clearer for a child with deafness (Souralová, 2002; Daňková, 2008). The conversion to sign language was consulted with adults with a hearing loss, using sign language as a primary means of communication. During the administration itself the children could choose whether they wanted formally adjusted items, items in sign language, or both. The administrator was a Czech sign language user. The items in sign language are available on $\mathrm{CD}$ for possible further use.

In the second administration all the rules according to the manual were followed again, with the exception of cancellation after the third failed answer in a row, again for the reason of collecting as much information as possible about comprehensibility and the functionality of the adjustments.

\section{Presentation of Results}

The precondition of the comparability of the results in both collection rounds was that the respondents would score better in the second round, and that the results would be more differentiated and closer to normal distribution.

The first method used to verify the results was descriptive statistics: 


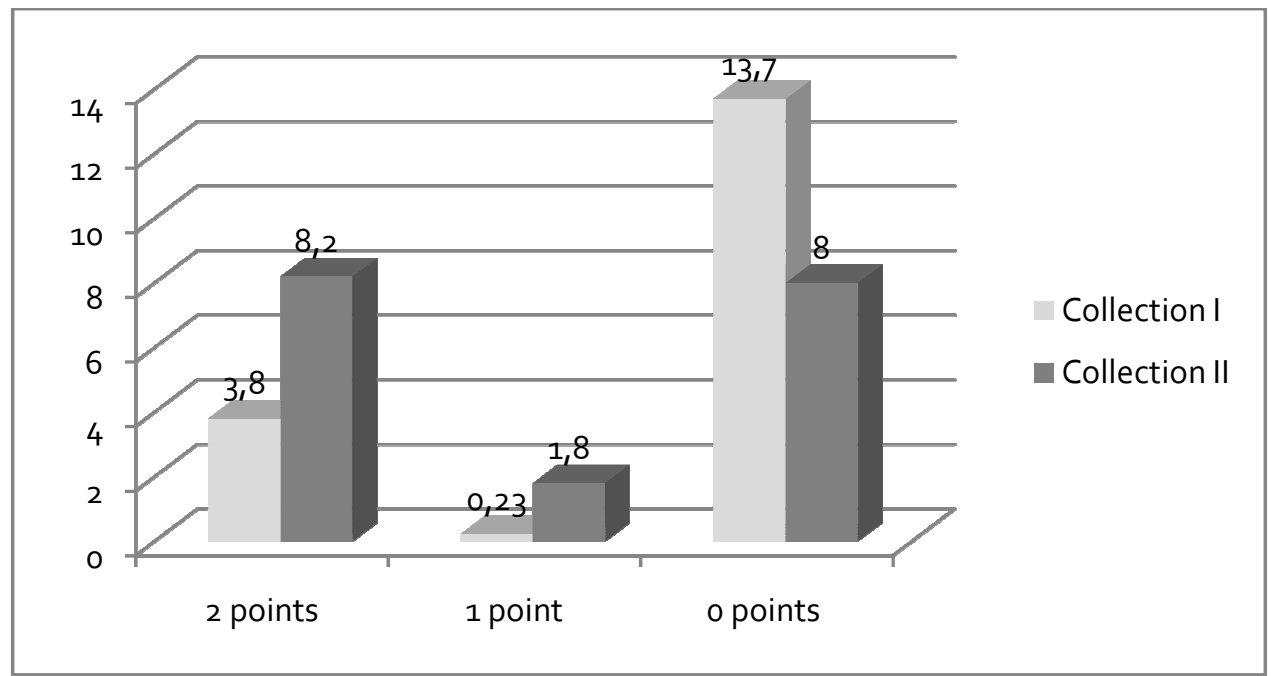

Fig. 1. Average occurrence of individual replies

It is clear from the graph that the number of replies that could have been evaluated by one or two points increased in the second round. This means the respondents understood more items, and the subtest became more differentiated.

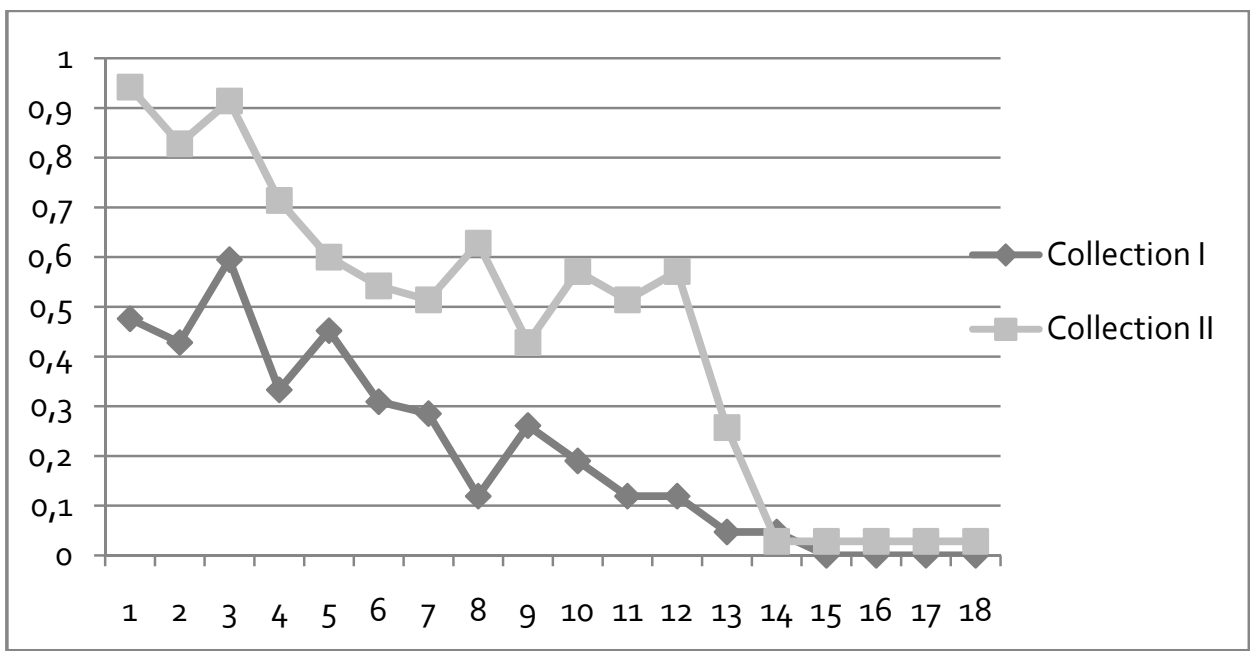

Fig. 2. Frequency of two-point replies for individual items 
The average weighted score in the first round was 3 , and in the second round 6. Only one subtest was used, so IQ cannot be established. It is possible to get equivalents of median test age to rough subtest scores using Table A.9. in the test manual. For the 11-15 age group the rough score should be between 20 and 26 points.

In the first round only two respondents achieved this (5\%). For the sake of completeness, these were respondents aged 11 years old, whose result was a rough score of 28 points. For this age the medium test median is set to 20 points. Both the respondents achieved better results.

This result was achieved by eight respondents $(23 \%)$ in the second round. Of those eight respondents one was of median age, one was better by one point, and the rest were, on average, five points better than the median test age.

The results show that the modified form of the subtest allows individuals with deafness to focus only on the content.

Statistical verification of the hypothesis followed the descriptive statistics. Is there a major statistical difference between the two rounds? An independent $\mathrm{t}$-test and F-test were used to verify the hypothesis. The statistical program SPSS, version 21, was used for the calculations.

The average values of the rough scores for the individual collection rounds were calculated first: in the first round $(\mathrm{n}=42)$ it was $7.8(\mathrm{~s}=1.2)$, and in the second $(\mathrm{n}=35)$ it was $18.2(\mathrm{~s}=1)$. A T-test subsequently proved a significant difference between the medians, and also on the 0.01level of significance. Following the results it was possible to reject zero hypotheses on the equality of both samples, which means the adjusted test version led to a statistically different (higher) score judged by the median.

The Levene's test, where the value $p$ is $(, 029) \leq 0,05$, also shows that there is a significant difference between the variances. This result was confirmed on the basis of an F-test, proving significant differences between the variances in both groups at the 0.01level of significance, and therefore $\mathrm{H} 0$ could be rejected. Other calculations showed that in the first round the data did not have normal distribution, while in the second round they did. This fact was verified using the Shapiro-Wilk test. As regards the first round we can reject $\mathrm{H} 0$ for normal distribution at the 0.01level of significance. Therefore, following the results of the F-test and Shapiro-Wilk test we can conclude that the adjusted version led to differentiation, i.e., the results are distributed.

The results show that the proposed adjustments are functional. Even though the differentiation of the results was proved statistically, and normal distribution was confirmed, the results of the children with deafness do not 
correspond to the norm: according to the Gauss normal distribution test medians should be achieved by about $68 \%$ of the respondents. In our case it was $5 \%$ and $23 \%$ respectively.

When administering the Comprehension test we often experienced a situation in which the children understood the question, and yet they did not know the answer (e.g., item 8 - switching off the lights). There is an obvious cause of this, the social and sensory deprivations that can occur as a consequence of deafness.

Social deprivation in relation to children with deafness is connected to the fact that many of these children spend their school years in a boarding house. Despite all the efforts of the staff this is not an environment that provides normal social situations - those encountered by their contemporaries in family surroundings.

As mentioned earlier, hearing is an important function that allows an individual to receive a large volume of information. When this function is disrupted, sensory deprivation may occur, manifested mostly in varying levels of communication skills, affecting verbal intelligence.

\section{Partial Summary}

Considering the results, the proposed formal adjustments of the test (modified wording of the items, conversion to sign language) appear to be functional. However, what remains to be discussed is the different level of verbal intelligence of individuals with deafness, as a result of the auditory disability itself.

\section{Discussion}

As stated above, the basic problem when using most of the psychodiagnostic tools and procedures for people with deafness is their low level of language skills. The present research was in the Czech language, but a similar situation can be expected in other languages. The point is the use of language as a communication instrument in both spoken and written form.

Camara describes the requirement for a considerate approach to examination, stressing the necessity to adjust the conditions and eliminate causes of stress and inappropriate strain during psychological testing. The same requirements can obviously be applied to children with deafness. Similarly, Camara and Lane comment on the issues of infant psycho-diagnostics, and 
mention the approach to result validation in the sense of the regulation from 2001 "No child left behind", which established the legislative framework for treating children with a hearing loss in the USA. Analytical work was performed by Eignor (2001) in the same environment, also focusing on the psychological examination of persons with disabilities, opening the "big topic" of the present, which is politically correct terminology. The issue is formulated as the risk of labeling tests and their results modified to accommodate the special needs of clients. So on the one hand we have "No child left behind", and on the other a complementary worry about labeling the clients. That is why it is recommended to provide a reason and type of modification only with the client's consent, which eliminates the possibility of unwanted notification of his/her disability. A specific area of infant diagnostics is communication and the related skills. Christensen et al. (2014) provided information on the topic, related to the examination of children with low potential in the area of the receptive component of communication. From their conclusions the primary necessity can be derived of the examination of communicative competences with clients suffering from disabilities affecting their psychomotor development. Such examination would not only bring an image of the area in an updated version (the authors point out developmental dynamics, which also implies the need for continuous diagnostics, i.e., always before the examination itself), but at the same time provide the possibility of eliminating the influence of language and communication skills on the process and especially on the result.

Fundamental principles were adopted for the above-mentioned modifications and verifications, described by Říčan. ${ }^{24}$ The author defines them as an ecological approach and the continuity principle, while both reflect the effort to accept children's requirements and thus to contribute to the highest possible objectivity of the examination. Svoboda approaches a psychological examination as a specific kind of interaction between a psychologist and client. According to this author, this interaction is influenced by several variables, which alone and in mutual interaction have an effect on the result (but the same applies to intervention). For both the activities it is necessary to consider - apart from other major conditions (personality, momentary and long-term setup) - social and communication potential. This includes not just local material-technical modifications and equipment, but also the form of administration, which will be adjusted to the age of the children, and if need be also to their individual specific requirements and needs.

${ }^{24}$ P. Říčan, D. Krejčířová, Dětská klinická psychologie, Grada, 1997, s. 238. 
With both the tools described above the present authors respected the above-mentioned requirements. After adjustment and the making of a video of not only the actual diagnostic tools but also of the administration, usable results were achieved.

If the procedures described here can be generalized, they respect the requirements specific to the group of clients with deafness. The requirement for a high level of communicability as an environmental characteristic is widely applied in pedopsychology. In the environment of a child with deafness the communicability requirement gains even more importance, and it becomes a necessary prerequisite. Communicability can be defined as a climate or atmosphere that is welcoming for a person with a lack of communication skills (where the child is led by an oral communication mode) or communication difference (in case the preferred channel is sign language). This means setting up the situations and activities in order to base the examinations on communication, i.e., also the accessibility of information for clients with deafness. It is always necessary to consider the facts that can substantially change not just the results of the diagnostic process, but also possible consequent consultancy or therapeutic steps and procedures. Another requirement was to respect the preferred communication style of the client, which can be characterized as acknowledgement of the right to choose the communication mode. The school environment is subject to special legislation; such a regulation should be respected by school psychologists as well. Professional sources mention attempts at correcting this situation; modified diagnostic tools are developed and standardized on the population with deafness. One of the possible solutions is administration and implementation using sign language, usually recorded. As regards the intervention and therapeutic techniques, it is an advantage when the psychologist can handle the client's communication channel - in this case sign language. It is possible to invite an interpreter, but this does not always bring about the desired diagnostic or intervention effect.

With the tools described here validity and reliability relevant to the defined requirements were achieved. The goal was to complete language adjustment of the text part, and at the same time to create a variant in sign language as an alternative form of examination of children with deafness.

\section{Declaration of interest}

Author A declares that he has no conflict of interest. Author B declares that she has no conflict of interest. The authors alone are responsible for the content and writing of the paper. 


\section{Compliance with Ethical Standards}

This article does not contain any studies with human participants or animals performed by any of the authors.

\section{BIBLOGRAPHY}

Chasid A., Visual Experience: Cognitive Penetrability and Indeterminacy, Acta Analytica: International Periodical for Philosophy in the Analytical Tradition, 2014, 29(1).

Daza M.T., Phillips-Silver J., Ruiz-Cuadra M.M., López-López F., Language skills and nonverbal cognitive processes associated with reading comprehension in deaf children, Research in Developmental Disabilities, 2014.

Deroy O., Object-Sensitivity versus Cognitive Penetrability of Perception, Philosophical Studies: An International Journal For Philosophy in The Analytic Tradition, 2013, 162(1).

Dupuis K., Pichora-Fuller M.K., Chasteen A.L., Marchuk V., Singh G., Smith S.L., Effects of hearing and vision impairments on the Montreal Cognitive Assessment, Aging, Neuropsychology \& Cognition, 2015, 22(4).

Ebrahim F., Comparing Creative Thinking Abilities and Reasoning Ability of Deaf and Hearing Children, Roeper Review, 2006, 28(3).

Fridland E.R., Skill, Non Propositional Thought, and the Cognitive Penetrability of Perception, Journal For General Philosophy of Science, 2015, 46(1).

Gates-Ulanet P., Mellon N.K., Psychosocial Aspects of Hearing Loss in Children, Otolaryngologic Clinics of North America, 2015, 48 (Hearing Loss in Children).

Guidelines for assessment of and intervention with persons with disabilities, American Psychologist, 2012, 67(1).

Harrington M., DesJardin J.L., Shea L.C., Relationships Between Early Child Factors and School Readiness Skills in Young Children With Hearing Loss, Communication Disorders Quarterly, 2010, 32(1).

Harris M., The Rise of Anthropological Theory: A History of Theories of Culture, AltaMira Press, London 2001.

Hofmann K., Chilla S., Bimodal Bilingual Language Development of Hearing Children of Deaf Parents, European Journal of Special Needs Education, 2015, 30(1).

Holmer E., Heimann M., Rudner M., Evidence of an association between sign language phonological awareness and word reading in deaf and hard-of-hearing children, Research in Developmental Disabilities, 2015.

Jacobs P.G., Psychosocial Potential Maximization: A Framework of Proactive Psychosocial Attributes and Tactics Used by Individuals who are Deaf, Volta Review, 2010, 110(1).

Koopmann M., Weiss D., Rudack C., A rare differential diagnosis of deafness, LaryngoRhino-Otologie, 2013, 92(2).

Lederberg A.R., Schick B., Spencer P.E., Language and literacy development of deaf and hardof-hearing children: Successes and challenges, Developmental Psychology, 2013, 49(1).

Lyxell B., Wass M., Sahlén B., Ibertsson T., Asker-Árnason L., Uhlén I., Möller C., Chapter 4: Hearing and cognitive development in deaf and hearing-impaired children. effects of intervention, Handbook of Clinical Neurophysiology, (Disorders of Peripheral and Central Auditory Processing), 2013, 10. 
Maller S.J., Deafness and WISC-III item difficulty: Invariance and fit, Journal of School Psychology, 1997, 35(3).

McKee M., Schlehofer D., Thew D., Ethical Issues in Conducting Research With Deaf Populations, American Journal of Public Health, 2013, 103(12).

Raftopoulos A., Cognitive Penetrability and Consciousness, Oxford University Press, Oxford 2015.

Říčan P., Krejčirrová D., Dětská klinická psychologie, Grada, 1997.

Savastano M., Characteristics of tinnitus in childhood, European Journal of Pediatrics, 2007, 166(8).

Savoldelli G., Extraversion (E), Neurotizismus (N) und Psychotizismus (P) bei Gehörlosen und Ertaubten, Archiv Für Psychiatrie Und Nervenkrankheiten, 1975, 220(3).

Slavík J., Chrz V., Štech S., Tvorba Jako Způsob Poznávání, Karolinum, Praha 2013.

Sorkin D.L., Gates-Ulanet P., Mellon N.K., Psychosocial Aspects of Hearing Loss in Children, Otolaryngologic Clinics of North America, 2015, 48 (Hearing Loss in Children).

Traxler C.B., The Stanford Achievement Test, 9th Edition: National Norming and Performance Standards for Deaf and Hard-of-Hearing Students, Journal of Deaf Studies and Deaf Education, 2000, 5(4).

Vágnerová M., Klégrová J., Poradenská psychologická diagnostika dětí a dospívajících, Karolinum, Praga 2008.

Wechsler D., The measurement of adult intelligence (3rd ed.), Williams \& Wilkins, Baltimore 1944.

Williams C., Mayer C., Writing in Young Deaf Children, Review of Educational Research, 2015, 85(4).

Zborteková K., Integrované vzdelávanie a kognitívny Vývin sluchovo postihnutých detí, Psychológia a patopsychológia diet'at'a", 2000, 1(35).

Zekveld A.A., Deijen J.B., Goverts S.T., Kramer S.E., The Relationship Between Nonverbal Cognitive Functions and Hearing Loss, Journal of Speech, Language \& Hearing Research, 2007, 50(1). 